Article

\title{
Influences of Magnesium Content in Rehydrated Mixed Oxides on Furfural Conversion
}

\author{
Kocík Jaroslav *D, Kolena Jiří, Akhmetzyanova Uliana $\mathbb{D}$ and Tišler Zdeněk (D) \\ Unipetrol Centre for Research and Education, 43670 Litvínov-Záluží 1, Czech Republic; \\ jiri.kolena@unicre.cz (K.J.); uliana.akhmetzyanova@unicre.cz (A.U.); zdenek.tisler@unicre.cz (T.Z.) \\ * Correspondence: Jaroslav.kocik@unicre.cz; Tel.: +420-471-122-234
}

Received: 18 November 2020; Accepted: 18 December 2020; Published: 19 December 2020

check for updates

\begin{abstract}
In this study, $\mathrm{Mg}-\mathrm{Fe}$ catalysts with various molar ratio (Mg/Fe 1:1-10:1), prepared by calcination and subsequent rehydration of hydrotalcite structures, were characterized, tested and evaluated as suitable catalysts for the aldol condensation of furfural with acetone. XRD analyses confirmed that the layered structure was completely restored by rehydration in the catalysts with $\mathrm{Mg}$ :Fe molar ratio 3:1 and 4:1. TPD- $\mathrm{CO}_{2}$ showed that the catalysts of this molar ratio had the highest basicity. Rehydrated Mg-Fe catalysts were tested in aldol condensation carried out in a glass batch reactor at $60{ }^{\circ} \mathrm{C}$, atmospheric pressure, $2 \mathrm{wt} \%$ of catalyst and acetone/furfural molar ratio 10:1. The catalysts with $\mathrm{Mg} / \mathrm{Fe}$ molar ratio of 3:1 and 4:1 showed total furfural conversion. As high basicity causes a high activity of the catalyst, our results suggest that the rehydrated mixed oxides with molar ratio 3 to 4:1 were promising new catalysts for the aldol condensation of furfural with acetone.
\end{abstract}

Keywords: Mg/Fe LDH; rehydration; aldol condensation

\section{Introduction}

Mixed oxides prepared from layered double hydroxides (LDH) by calcination are intensively studied materials as new environmentally friendly catalysts. The structure of LDHs is derived from brucite $\left[\mathrm{Mg}(\mathrm{OH})_{2}\right]$ where part of magnesium ions was substituted by trivalent ions and formed a cation layer. An excess of positive charges is compensated by anions, which are located in the interlayer. Moreover, water molecules are situated in the free space between anions [1,2]. LDHs are represented by general formula $\left[\mathrm{M}_{1-\mathrm{x}}^{\mathrm{II}} \mathrm{M}_{\mathrm{x}}^{\mathrm{III}}(\mathrm{OH})_{2}\right]^{\mathrm{x}+}\left(\mathrm{A}_{\mathrm{x} / \mathrm{n}}^{\mathrm{n}-} \cdot \mathrm{m} \mathrm{H}_{2} \mathrm{O}\right)^{\mathrm{x}-}$, where $\mathrm{M}$ is a divalent $\left(\mathrm{Mg}^{2+}, \mathrm{Zn}^{2+}, \mathrm{Ca}^{2+}\right)$ or a trivalent cation $\left(\mathrm{Al}^{3+}, \mathrm{Cr}^{3+}, \mathrm{Fe}^{3+}\right)$ respectively [3]. Anions are denoted by $\left(\mathrm{A}^{\mathrm{n}-}\right)_{\mathrm{x} / \mathrm{n}}$, where $\mathrm{x}$ is concentration of trivalent cations and it reaches the values between 0.20 and 0.33 [1]. The properties of $\mathrm{LDH}$ and the mixed oxide prepared from it can be modified by the molar ratio of divalent and trivalent cations and also by the type of intercalated cations.

The molar ratio of bivalent and trivalent cations significantly influences acid-based properties of the mixed oxides. The basicity increases with increasing the $\mathrm{Mg} / \mathrm{Al}$ molar ratio to 3:1. However, with further increase of the magnesium content, the basicity significantly decreases [4]. Kutalek et al. studied the influence of $\mathrm{Mg} / \mathrm{Al}$ molar ratio in a wide range, from 1.8 to 7.2 and showed that the basicity decreased with increasing the molar ratio up to 3.6. Further increase of the $\mathrm{Mg} / \mathrm{Al}$ molar ratio did not significantly change the catalysts basicity [5]. The $\mathrm{Mg} / \mathrm{Al}$ molar ratio influences also some properties like the catalyst particle size or specific surface area, which increases with increasing the molar ratio [5]. The properties of the mixed oxides could vary in dependence on the bivalent and trivalent metal types. Little attention has been paid to $\mathrm{Mg}$-Fe mixed oxides so far, while the $\mathrm{Mg}$-Al mixed oxides have been widely investigated.

The Mg-Fe mixed oxides are characterized with wide distribution of basic sites, which depends on the $\mathrm{Mg} / \mathrm{Fe}$ molar ratio [6]. Basicity increases with the $\mathrm{Mg} / \mathrm{Fe}$ molar ratio increase, which is caused 
by the increase of the strong basic sites. Further increase of the total basicity of the mixed oxides can be achieved by rehydration. The rehydration of the $\mathrm{Mg}$-Fe mixed oxides rebuilds the layered structure of LDHs, which can increase the basicity in return. The distribution of basic sites as well as the total catalyst basicity influences the activity of the catalyst in many reactions such as Michael addition [7], transesterification [5], Knoevenagel [8], Claisen-Schmidt [9] and aldol condensation [10].

The aldol condensation yields in molecules with longer carbon chains, which in some cases may be used as renewable fuel components, after being hydrogenated. Furfural is a low molecular weight keto-compound possibly derived from biomass, which can be converted with acetone to $\mathrm{C} 8$ and $\mathrm{C} 13$ compounds such as 4-(2-furyl)-4-hydroxybutane-2-one (FAc-OH), which subsequently reacts to 4-(2-furyl)-3-butene-2-one (FAc) and 1,4-pentadiene-3-on-1,5-di-2-furanyl ( $\mathrm{F}_{2} \mathrm{Ac}$ ) (Figure 1) [11,12],. Furfural is produced by acid-catalyzed decomposition of hemicellulose rich sources like bagasse, rice husk, corn cobs or sugarcane [13]. Alternatively, acetone is produced as a by-product in phenol production. New methods of producing acetone from biomass are currently being investigated using enzymatic catalysis [14].

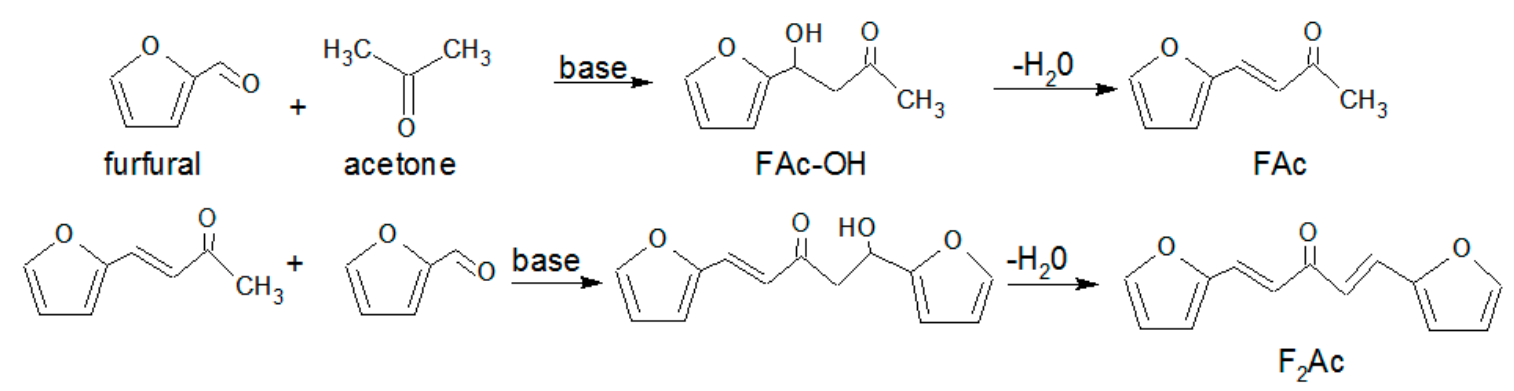

Figure 1. Reaction scheme of aldol condensation.

This work is focused on the study of the effect of magnesium content on the structure of $\mathrm{Mg}$-Fe LDHs, which can be effective alternatives to $\mathrm{Mg}$-Al hydrotalcites which have been described in more details in the literature. The Mg-Fe mixed oxides were prepared by calcination and then they were rehydrated. The structural and acid-basic properties of the rehydrated mixed oxides were compared with their catalytic properties in aldol condensation of furfural with acetone.

\section{Results and Discussion}

\subsection{Structural and Textural Properties of Mg-Fe LDH and Mixed Oxide}

The LDH structure of the products of precipitation was confirmed by XRD. The XRD patterns of LDHs with different $\mathrm{Mg} / \mathrm{Fe}$ molar ratio are depicted in Figure $2 \mathrm{~A}$, where the diffraction lines at $2 \theta=10.4^{\circ}, 22.8^{\circ}, 34.1^{\circ}, 38.4^{\circ}, 45.5^{\circ}, 59.3^{\circ}$ and $60.6^{\circ}$, typical for double layered hydroxides, can be seen [15]. The LDHs with the $\mathrm{Mg} / \mathrm{Fe}$ molar ratio in the range from 1:1 to 4:1 are represented by sharp, intensive and symmetric diffraction lines, which indicate well ordered crystal structure of the samples. For higher $\mathrm{Mg} / \mathrm{Fe}$ molar ratio, the diffraction lines are less sharp and symmetric which is more and more apparent with increasing magnesium content.

No diffraction lines typical for LDHs were observed in the mixed oxides prepared by calcination, which indicates that the LDHs to mixed oxides transformation was complete (Figure 2B) in the calcined samples. The diffraction lines at $2 \theta=42.9^{\circ}$ and $62.2^{\circ}$ indicate the presence of $\mathrm{MgO}$. The crystal structure of the $\mathrm{Mg}$-Fe mixed oxides is influenced by the $\mathrm{Mg} / \mathrm{Fe}$ molar ratio. The higher molar ratio the better developed crystal structure. The $\mathrm{LDHs}$ with high $\mathrm{Mg} / \mathrm{Fe}$ molar ratio had intensive sharp diffraction lines, characteristic for $\mathrm{MgO}$, which means that not all $\mathrm{MgO}$ was intercalated to the crystal lattice and formed a separated phase. This phenomenon was also mentioned in our previous work [6]. The Mg-Fe mixed oxides with the $\mathrm{Mg} / \mathrm{Fe}$ molar ratio of $1: 1$ contained also a second pure phase, determined as magnetite $\left(\mathrm{Fe}_{3} \mathrm{O}_{4}\right)$ with diffraction lines at $2 \theta=35.5^{\circ}$, besides the mixed oxide. 

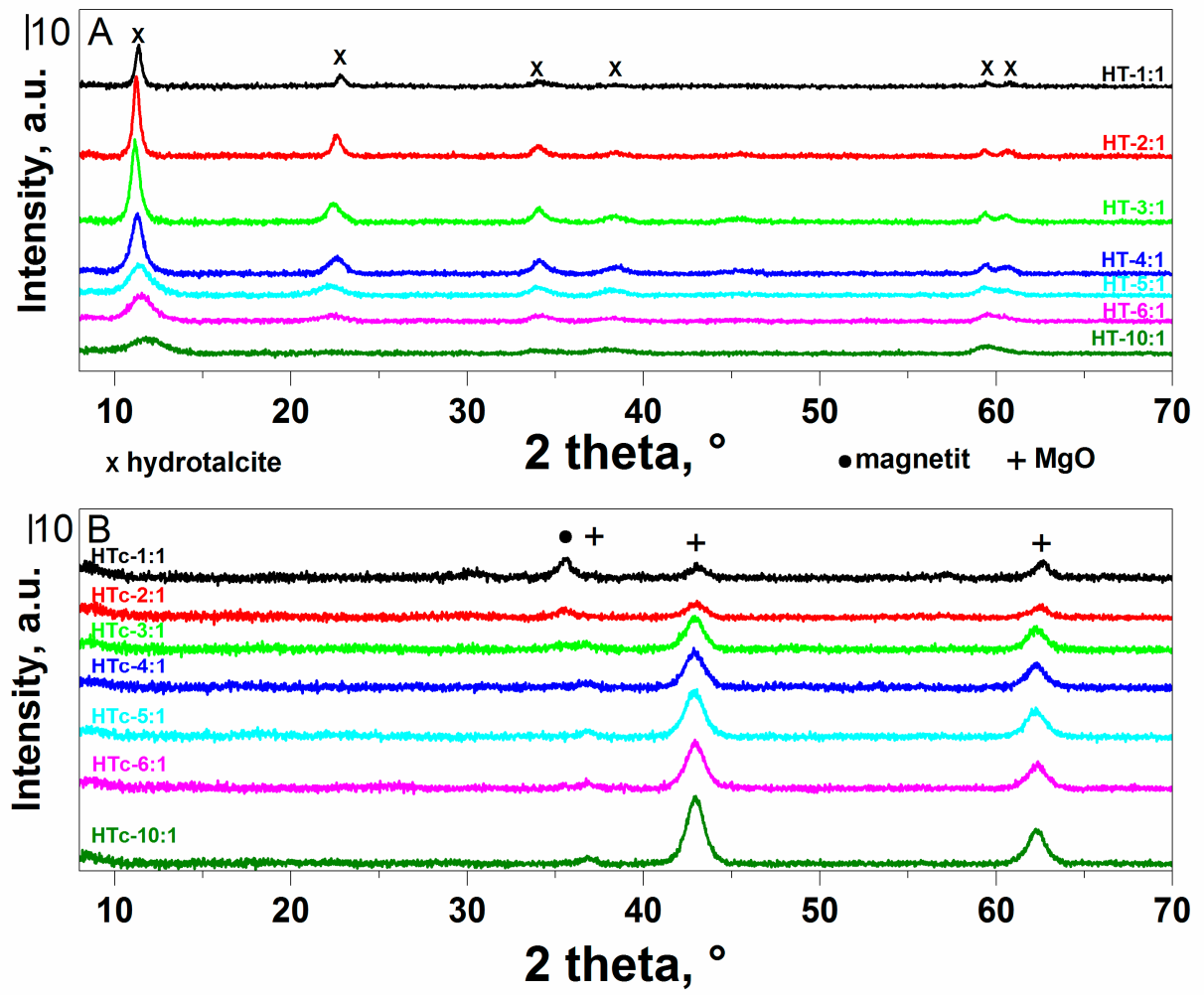

Figure 2. XRD of LDHs (A) and Mg-Fe mixed oxides (B) with different $\mathrm{Mg} / \mathrm{Fe}$ molar ratios.

After contacting the Mg-Fe mixed oxides with water (rehydration), the layered structure of LDHs was recovered. Figure 3 shows diffraction lines at $2 \theta=10.4^{\circ}, 22.8^{\circ}, 34.1^{\circ}, 38.4^{\circ}, 45.5^{\circ}, 59.3^{\circ}$ and $60.6^{\circ}$, which correspond to the layered structure and confirmed [16], that the rehydration of mixed oxides was successful.

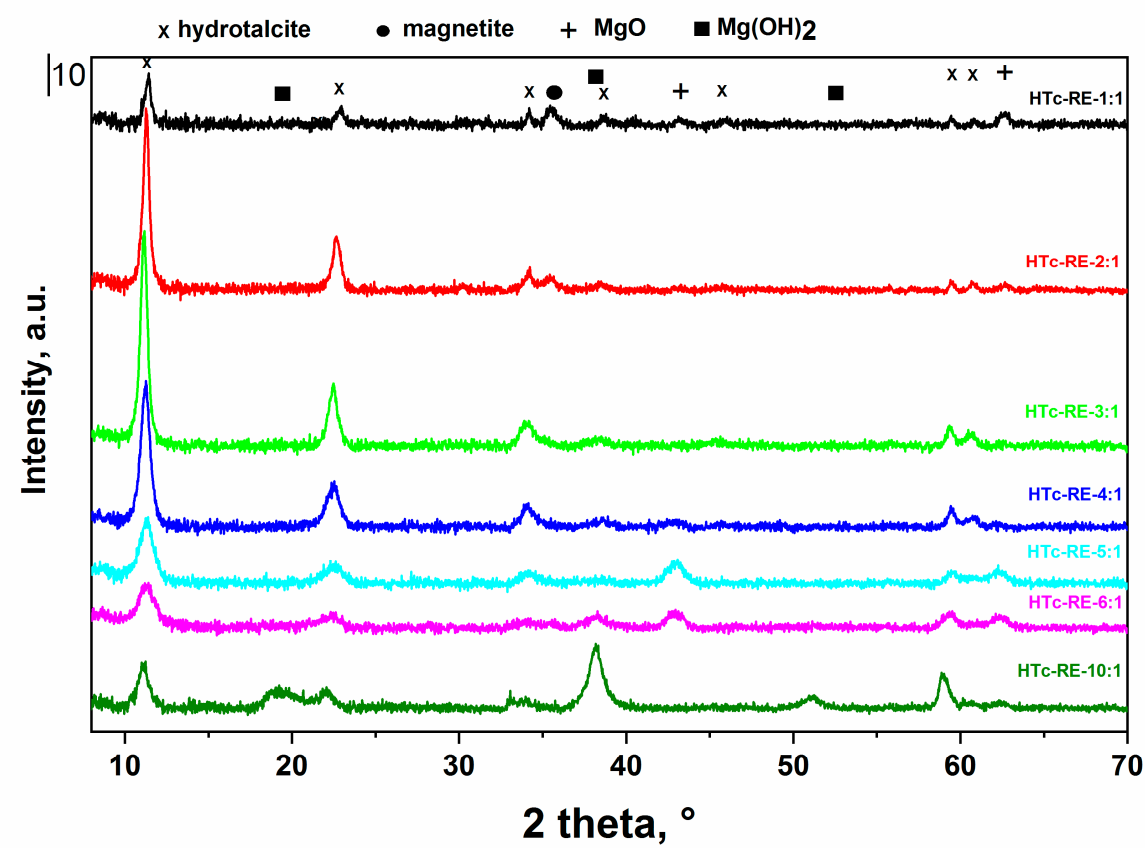

Figure 3. XRD of rehydrated mixed oxides with different $\mathrm{Mg} / \mathrm{Fe}$ molar ratio.

However, the diffraction lines at $2 \theta=35.5^{\circ}$, which are characteristic for magnetite $\left(\mathrm{Fe}_{3} \mathrm{O}_{4}\right)$ were observed at $\mathrm{Mg}$-Fe rehydrated mixed oxides with the $\mathrm{Mg} / \mathrm{Fe}$ molar ratio 1:1 and 2:1respectively. On the 
other hand, the diffraction lines at $2 \theta=43.0^{\circ}$ a $62.5^{\circ}$ [17], indicating the presence of $\mathrm{MgO}$, were observed in samples HTc-RE-1:1, HTc-RE-5:1 and HTc-RE-10:1. The diffraction lines at $2 \theta=19.0^{\circ}, 38.2^{\circ}$ a $51.1^{\circ}$ characteristic for brucite $\left(\mathrm{Mg}(\mathrm{OH})_{2}\right)$ are observed in HTc-RE-10:1. Pure LDH phase was formed in the samples with the $\mathrm{Mg} / \mathrm{Fe}$ molar ratio 3:1 and 4:1 respectively. The rehydrated mixed oxides with low $\mathrm{Mg} / \mathrm{Al}$ molar ratio contained also $\mathrm{MgO}$ besides hydrotalcite phase, while the diffraction lines of $\mathrm{MgO}$ and $\mathrm{Mg}(\mathrm{OH})_{2}$ were observed in the XRD pattern of the rehydrated $\mathrm{Mg}$-Fe mixed oxides with higher $\mathrm{Mg}$ content. Sharp, intensive and symmetric diffraction lines can be observed in the rehydrated mixed oxides with $\mathrm{Mg} / \mathrm{Fe}$ molar ratio from 2 to 4 , which shows on well ordered crystal structure of the samples.

The lattice parameters a and c (see Table 1) were calculated from the diffraction lines at 59.3 and $10.4^{\circ}$ respectively. The lattice parameter $a$ represents the cation-cation distance. The value of the lattice parameter $a$ is similar for the rehydrated mixed oxides with the molar ratio $\mathrm{Mg} / \mathrm{Fe}$ up to 4:1. However, with further increase of the amount of magnesia in the lattice, the lattice parameter $a$ increased from 0.310 to $0.313 \mathrm{~nm}$. The same results were presented also for $\mathrm{Mg}$-Al hydrotalcites [5,18]. The lattice parameter $c$ represents the distance of three anion and cation layers. The value of the lattice parameter $c$ was in the range from 2.333 to $2.402 \mathrm{~nm}$ and increased with increasing the $\mathrm{Mg} / \mathrm{Fe}$ molar ration. This could be caused by the electric charge between anion and cation layers [19]. However, a slight decline was observed in the molar ratio range from 3:1 to 5:1.

Table 1. Unit cell parameters, Crystallite Sizes and Specific Surface Areas determined for the $\mathrm{Mg} / \mathrm{Fe}$ rehydrated mixed oxides, composition of the LDH.

\begin{tabular}{ccccccc}
\hline Catalyst & $\mathbf{a}, \mathbf{n m}$ & $\mathbf{c}, \mathbf{n m}$ & $\mathbf{D}, \mathbf{n m}$ & $\mathbf{S}_{\text {BET }, \mathbf{~ m}^{\mathbf{2}} \mathbf{g}}$ & $\mathbf{M g}, \mathbf{w t} \mathbf{0}$ & $\mathbf{F e}, \mathbf{w t} \mathbf{o}$ \\
\hline HTc-Re-1:1 & 0.304 & 2.333 & 17 & 55 & 15.0 & 35.0 \\
HTc-Re-2:1 & 0.305 & 2.352 & 22 & 98 & 20.7 & 24.2 \\
HTc-Re-3:1 & 0.305 & 2.381 & 19 & 121 & 22.9 & 17.6 \\
HTc-Re-4:1 & 0.304 & 2.363 & 14 & 97 & 24.9 & 15.0 \\
HTc-Re-5:1 & 0.310 & 2.351 & 9 & 41 & 27.1 & 12.9 \\
HTc-Re-6:1 & 0.311 & 2.369 & 5 & 115 & 28.9 & 12.1 \\
HTc-Re-10:1 & 0.313 & 2.402 & 10 & 49 & 31.9 & 10.1 \\
\hline
\end{tabular}

Scherrer equation was used for calculation of crystal size, which was determined by the diffraction line at $2 \theta=10.4^{\circ}$. The crystal size decreased from 22 to $5 \mathrm{~nm}$ with the $\mathrm{Mg} / \mathrm{Fe}$ molar ratio increase. The differences were observed in the HTc-RE-1:1 and HTc-Re-10:1, where the crystal size values were determined as $17 \mathrm{~nm}$ and $10 \mathrm{~nm}$, respectively.

Surface area was determined by $\mathrm{N}_{2}$-physisorption and the results are presented in Table 1 . The surface area of rehydrated mixed oxides reached values in the range from 41 to $121 \mathrm{~m}^{2} / \mathrm{g}$. The value of surface area increased in line with the $\mathrm{Mg} / \mathrm{Fe}$ molar ratio increase, up to the value of 3:1 $\left(121 \mathrm{~m}^{2} / \mathrm{g}\right)$. Higher content of magnesium in the lattice caused a decrease of the specific surface area which was significant mainly for very high values of the $\mathrm{Mg} / \mathrm{Fe}$ molar ratio. So, the value of the specific surface area for -HTc-RE-6:1 was $115 \mathrm{~m}^{2} / \mathrm{g}$ while the surface area of $49 \mathrm{~m}^{2} / \mathrm{g}$ was determined for -HC-Re-10:1. The latest contained also the brucite phase, as confirmed by XRD. Kikhtyanin et al. [20] reported the brucite specific area of $157.2 \mathrm{~m}^{2} / \mathrm{g}$. However, if brucite was in the mixture with $\mathrm{Mg}$-Al hydrotalcite, the specific surface area decreased to $64 \mathrm{~m}^{2} / \mathrm{g}$. The mixture of hydrotalcite and $\mathrm{MgO}$ was formed during the synthesis of Mg-Al hydrotalcits with $\mathrm{Mg} / \mathrm{Al}$ molar ratio of 10:1. However, $\mathrm{Mg}$-Fe rehydrated mixed oxides are characterized with higher specific surface area in comparison with $\mathrm{Mg}$-Al hydrotalcites. The presence of other phases with lower crystallinity influenced positively the specific surface area of $\mathrm{Mg}$-Fe rehydrated mixed oxides. The highest specific surface area was determined for $\mathrm{Mg}$-Fe rehydrated mixed oxides with the Mg:Fe molar ratio ranging from 2:1 to 4:1 There were observed the diffraction lines typical for layered structure, in the XRD patterns of these samples.

TGA and dTG curves of Mg-Fe rehydrated mixed oxides are shown in Figure 4. Two main steps of mass release were observed as apparent from Figure 4 . The total weight loss determined ranged from 
$27.4 \mathrm{wt} \%$ to $50.4 \mathrm{wt} \%$ in the temperature interval from $25^{\circ} \mathrm{C}$ to $900{ }^{\circ} \mathrm{C}$. In the first step, which was observed between $40^{\circ} \mathrm{C}$ and $180^{\circ} \mathrm{C}$, water was released. The water was bound in the anion layer. It was either physically adsorbed or present in the form of moisture, which was not removed during the drying after rehydration. Two maxima on dTGA curve were observed at the temperature interval from $72{ }^{\circ} \mathrm{C}$ to $119^{\circ} \mathrm{C}$. The maximum at the temperature of $72{ }^{\circ} \mathrm{C}$ can be attributed to the remainders of moisture, which were not removed by drying after rehydration. The second maximum at 115 ${ }^{\circ} \mathrm{C}$, observed in the rehydrated mixed oxides with the molar ratio 5:1 and 10:1, can be attributed to physically adsorbed water and the water bound in the anion layer. The signals for Mg-Fe LDH were also observed. On the other hand, only one signal with maximum at $115^{\circ} \mathrm{C}$ was observed for HTc-Re-6:1. TGA results show, that the amount of moisture remainders was different in rehydrated mixed oxides with different molar ratio of metals though the drying was carried out the same way and for the same period of time (40 min). The highest amount of water released in the first step was observed in case of HTc-Re-2:1.
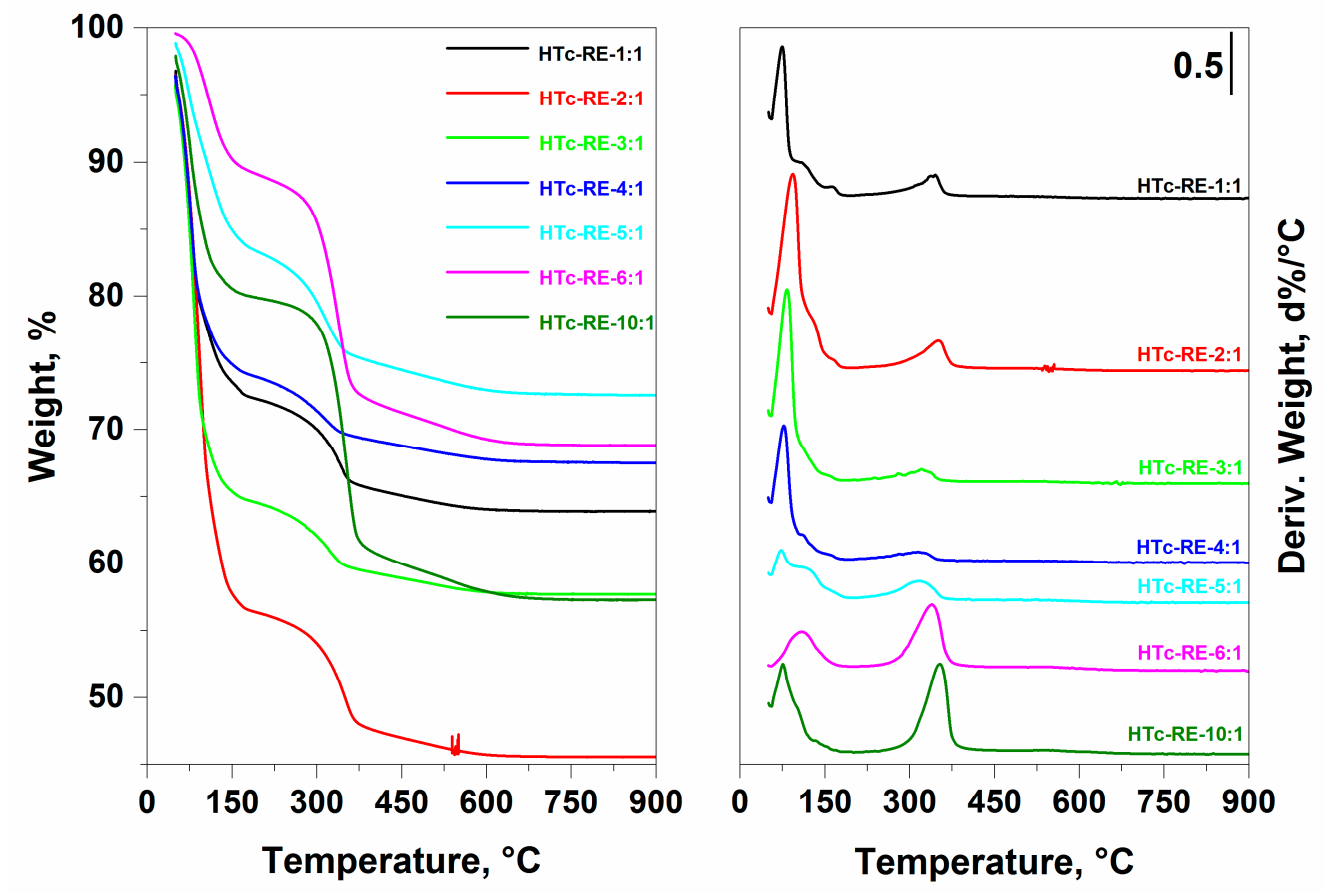

Figure 4. TGA and dTGA curves of rehydrated mixed oxides.

The second maximum on the TGA curve, in the temperature range between $220^{\circ} \mathrm{C}$ and $450{ }^{\circ} \mathrm{C}$, signalizes dehydroxylation of the cation layer. The maximum of this water release signal lays between $315^{\circ} \mathrm{C}$ and $354^{\circ} \mathrm{C}$. A shift of this TGA curve maximum to higher temperature was observed with the increase of the $\mathrm{Mg} / \mathrm{Fe}$ molar ratio from 3:1 to 10:1. The water rerelease at high temperature is most probably caused by decomposition of the brucite layer, which takes place at $393^{\circ} \mathrm{C}[21,22]$. Mass analyses of released compounds confirmed the presence of water only. The amount of the released water represented $5.2 \mathrm{wt} \%$ to $9.5 \mathrm{wt} \%$ in case of the rehydrated mixed oxides with the molar ratio up to 5:1. Finally, slight release of water, representing the amount of $1.14 \mathrm{wt} \%$ to $2.64 \mathrm{wt} \%$, was observed at the temperature higher than $450{ }^{\circ} \mathrm{C}$.

\subsection{Basic Properties}

TPD- $\mathrm{CO}_{2}$ curves are presented in Figure 5. The first desorption signal of lower intensity was observed in relatively wide temperature range, between $25^{\circ} \mathrm{C}$ and $250^{\circ} \mathrm{C}$. The second desorption was observed in the temperature range from $383^{\circ} \mathrm{C}$ to $425^{\circ} \mathrm{C}$. The maximum of the second desorption wave 
was shifted to higher temperatures when the $\mathrm{Mg} / \mathrm{Fe}$ molar ratio increased, from 1:1 to 4:1. This indicates the presence of stronger basic sites at higher molar ratio values.

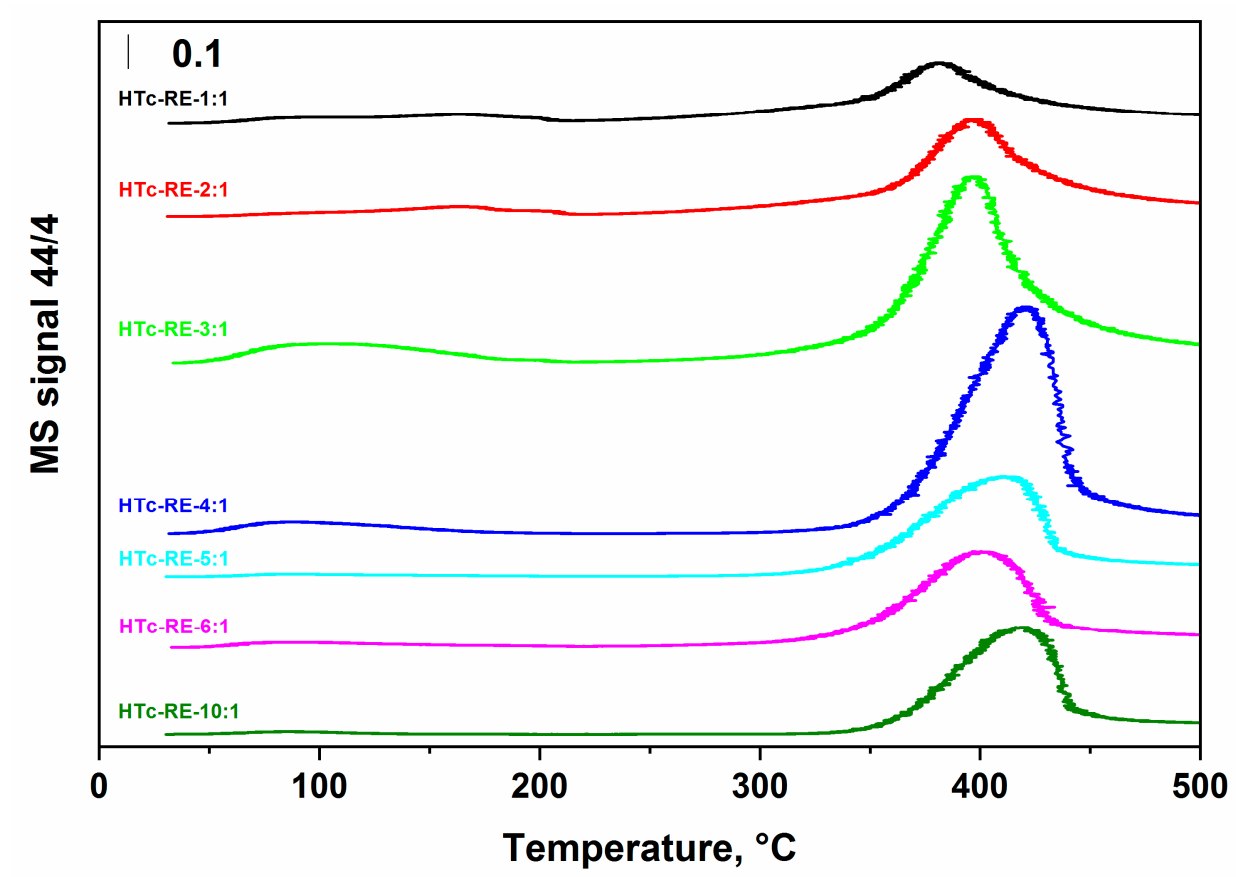

Figure 5. TPD- $\mathrm{CO}_{2}$ curves of rehydrated mixed oxides.

The catalysts basicity (total concentration of basic sites) was determined by the curve calibration method. $\mathrm{CO}_{2}$ was determined by mass spectrometry. Total basicity of $\mathrm{Mg}$-Fe rehydrated mixed oxides reached values in the range from $580 \mu \mathrm{mol} / \mathrm{g}$ to $1507 \mu \mathrm{mol} / \mathrm{g}$. Total basicity increased in line with increasing $\mathrm{Mg} / \mathrm{Fe}$ molar ratio up to 4:1. Then it started declining with further increase of said molar ratio. The highest amount of basic sites was indicated in HTc-RE-4:1. Moreover, the basic sites were strongest in this sample because the maximum of the desorption peak was achieved at highest temperature.

The determination of total amount of basic sites in rehydrated mixed oxides is complicated, because several disturbing phenomena may influence the measurement results. The layered structure of $\mathrm{LDH}$, confirmed in the Mg-Fe rehydrated mixed oxides by XRD, contain water in the anion layer. Carbon dioxide can be dissolved in this water even prior the pre-adsorption before the $\mathrm{CO}_{2}-\mathrm{TPD}$ measurement. Moreover, the layered structure of $\mathrm{LDH}$ can collapse, $\mathrm{CO}_{2}$ form the anion layer can be thus released and increase the total amount of $\mathrm{CO}_{2}$ from the second desorption at higher temperature. Therefore, the amount of total basic sites could be overestimated in this case. Nevertheless, the physically adsorbed water and the water bound in the anion layer were released at the temperature up to $180^{\circ} \mathrm{C}$. No relations among the amount of physically adsorbed water, the water contained in the anion layer and the amount of carbon dioxide released up to $250{ }^{\circ} \mathrm{C}$, were observed. So, no influence of the released water on the basic sites determination results is supposed.

\subsection{Aldol Condensation}

The rehydrated $\mathrm{Mg}$-Fe mixed oxides with different $\mathrm{Mg} / \mathrm{Fe}$ molar ratio values were tested in aldol condensation of furfural with acetone at following reaction conditions: $12 \mathrm{wt} \%$ of catalyst in relation to furfural, temperature of $50^{\circ} \mathrm{C}$, acetone to furfural molar ratio 10:1, stirring speed of $550 \mathrm{rpm}$. The testing results (conversion and selectivity to main products) are shown in Figure 6. The reaction rate increased in line with the $\mathrm{Mg} / \mathrm{Fe}$ molar ratio, this ratio increasing from 1:1 to 5:1. Furfural conversion of $100 \%$ was achieved after $40 \mathrm{~min}$ over the rehydrated mixed oxides with the molar ratio ranging from 3:1 to 5:1. In contrary, only $80 \%$ furfural conversion was achieved after $4 \mathrm{~h}$ of reaction time over HTc-RE-1:1 
(Figure 6A). The presence of Brönsted basic sites in the catalyst is the reason of its high activity in aldol condensation of furfural with acetone [23]. The rehydration of $\mathrm{Mg} / \mathrm{Fe}$ mixed oxides led to the transformation of Lewis sites to Brönsted active sites [24]. Kikhtyanin et al. reported, that the activity of MgGa mixed oxides incressed dramatically after their rehydration [23]. Furfural conversion correlated well with the density of basic sites, the values of which are presented in Table 2.
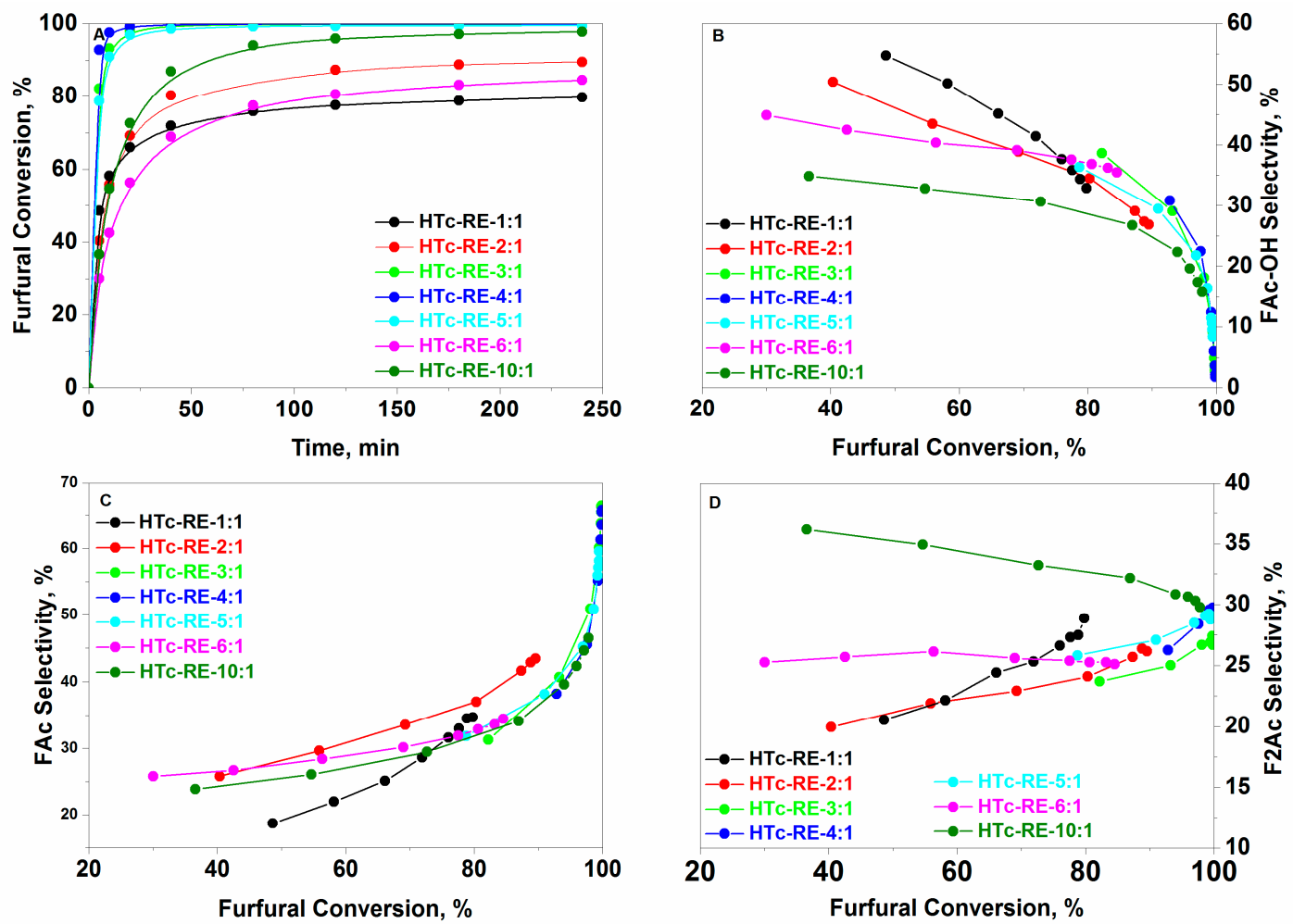

Figure 6. Furfural conversion (A) and main products selectivity $((\mathbf{B})=\mathrm{FAc}-\mathrm{OH} ;(\mathbf{C})=\mathrm{FAc} ;(\mathbf{D})=\mathrm{F} 2 \mathrm{Ac})$.

Table 2. Total amount of basic sites and density of basic sites of rehydrated mixed oxides.

\begin{tabular}{|c|c|c|}
\hline Catalyst & Basicity, $\mu \mathrm{mol} / \mathrm{g}$ & Density of Basic Sites, $\mu \mathrm{mol} / \mathrm{m}^{2}$ \\
\hline HTc-Re-1:1 & 580 & 10.55 \\
\hline HTc-Re-2:1 & 838 & 8.55 \\
\hline HTc-Re-3:1 & 1434 & 11.86 \\
\hline HTc-Re-4:1 & 1506 & 15.53 \\
\hline HTc-Re-5:1 & 956 & 23.34 \\
\hline HTc-Re-6:1 & 872 & 7.61 \\
\hline HTc-Re-10:1 & 779 & 15.91 \\
\hline
\end{tabular}

The main compounds determined in the reaction product led to a suggestion of the reaction scheme (Figure 1). The selectivity to FAc-OH decreased with increasing furfural conversion. The alcohol mentioned is a reactive intermediate which tends to react rapidly to the condensation product (FAc) - see Figure 6B. Conversely, the selectivity to FAc increased with increasing the furfural conversion. It reached the value of $65 \%$ after $4 \mathrm{~h}$ of reaction time over rehydrated mixed oxides HTc-RE-3:1 and HTc-RE- $4: 1$ as well (Figure 6C). FAc is converted to F2Ac by aldol-condensation. The selectivity to F2Ac is presented in Figure 6D. The dependence of selectivity to F2Ac on furfural conversion is influenced by the nature of catalyst, namely by its $\mathrm{Mg} / \mathrm{Fe}$ molar ratio. The decrease of selectivity to F2Ac with furfural conversion increase was observed only with HTC-RE-10:1. It could have been caused by the presence of other phases like $\mathrm{MgO}$ and $\mathrm{Mg}(\mathrm{OH})_{2}$. The presence of $\mathrm{Mg}(\mathrm{OH})_{2}$ in the mixed oxides has a negative impact on their activity in the aldol condensation of acetone with furfural and the formation of main condensation 
products (FAc and F2Ac) [23]. Selectivity to the side condensation products and polycondensates reached $3 \%$ to $8 \%$ after $4 \mathrm{~h}$.

The stability of the HTc-Re catalysts was also studied. The concentrations of magnesium and iron ions in the products of aldol-condensation were determined and compared with the composition of the catalysts (Table 3). The loss of the catalysts mas to the reaction mixture products by leaching of metals was negligible in the range from $2.81 \times 10^{-3}$ to $4.02 \times 10^{-2} \mathrm{wt} \%$ of the catalyst. Therefore the HTc-Re are evidently stable in the aldol-condensation of furfural with acetone.

Table 3. Concentration of the metal in products of aldol condensation acetone with furfural.

\begin{tabular}{ccc}
\hline Catalyst & $\mathbf{M g}, \mathbf{p p m}$ & $\mathbf{F e}, \mathbf{p p m}$ \\
\hline HTc-Re-1:1 & 0.157 & 0.456 \\
HTc-Re-2:1 & 0.1 & 0.28 \\
HTc-Re-3:1 & 0.32 & 0.355 \\
HTc-Re-4:1 & 5.28 & 3.46 \\
HTc-Re-5:1 & 4.34 & 2.35 \\
HTc-Re-6:1 & 3.84 & 1.92 \\
HTc-Re-10:1 & 3.17 & 1.02 \\
\hline
\end{tabular}

\section{Materials and Methods}

\subsection{Catalyst Synthesis}

$\mathrm{Mg}$-Fe LDHs were prepared by the co-precipitation method in a $5 \mathrm{~L}$ glass reactor Syrris Globe (Syrris Ltd., Royston, UK) equipped propeller stirrer, $\mathrm{pH}$ probe and two pumps. The solution of nitrates was prepared by dissolution of desired amounts of starting components $\left(\mathrm{Mg}\left(\mathrm{NO}_{3}\right)_{2} \cdot 6 \mathrm{H}_{2} \mathrm{O}\right.$ and $\mathrm{Fe}\left(\mathrm{NO}_{3}\right)_{3} \cdot 9 \mathrm{H}_{2} \mathrm{O}$; supplied by Lach-Ner, s.r.o., Neratovice, Czech Republic) in the amounts responding to total concentration of cations of $1 \mathrm{~mol} \cdot \mathrm{dm}^{-3}$. The nitrates solution was continuously injected into the reactor and the mixture was intensive stirred $(250 \mathrm{rpm})$ at $60^{\circ} \mathrm{C}$. The $\mathrm{pH}$ value of the reaction mixture was maintained at 9.5 by controlled injection of basic solution containing potassium carbonate $\mathrm{K}_{2} \mathrm{CO}_{3}$ (Penta, Chrudim, Czech Republic) and potassium hydroxide $\mathrm{KOH}$ (Lach-Ner, s.r.o., Neratovice, Czech Republic) $\left(\mathrm{cKOH}=2 \mathrm{~mol} / \mathrm{dm}^{3}+\mathrm{cK}_{2} \mathrm{CO}_{3}=0.2 \mathrm{~mol} / \mathrm{dm}^{3}\right)$. After precipitation, the mixture was left to be aged at $60{ }^{\circ} \mathrm{C}$ for $1 \mathrm{~h}$. LDH thus prepared was then filtered by the press-filtration using the filter paper plate S15N (Hobra, s.r.o., Broumov, Czech Rebublic) and washed with demineralized water (until $\mathrm{pH}$ of the filtrate reached the value of 7). Finely, the $\mathrm{LDH}$ was dried overnight at $65^{\circ} \mathrm{C}$. The LDHs were denoted as HT-xx, where $\mathrm{xx}$ is the Mg-Fe molar ratio.

The calcination of LDHs for the mixed oxides formation was carried out in a muffle oven at $500{ }^{\circ} \mathrm{C}$ (heating rate of $5^{\circ} \mathrm{C} \cdot \mathrm{min}^{-1}$ ) during $3 \mathrm{~h}$. The mixed oxides were denoted as HTc-xx, where $\mathrm{xx}$ is the $\mathrm{Mg} / \mathrm{Fe}$ molar ratio.

The rehydration of Mg-Fe mixed oxides was carried out in a $250 \mathrm{~mL}$ glass reactor placed in a water bath and equipped with a magnetic stirrer. The synthesized mixed oxide was placed in the reactor with $30 \mathrm{~g}$ of water and stirred $(550 \mathrm{rpm})$ at $25{ }^{\circ} \mathrm{C}$ for $30 \mathrm{~min}$. Then the rehydrated mixed oxide ("reconstructed" LDH) was separated by filtration and dried in a flow of nitrogen in a vacuum evaporator at $50{ }^{\circ} \mathrm{C}, 60 \mathrm{rpm}$ for $40 \mathrm{~min}$. The rehydrated mixed oxides were denoted as HTc-Re-xx, where $\mathrm{xx}$ is the molar ratio of $\mathrm{Mg} / \mathrm{Fe}$.

\subsection{Characterisation of Catalyst}

Chemical composition of mixed oxides and concentration of the metals in products were determined using ICP-OES technique analysis (Agilent 725, Agilent Technologies Inc., Santa Clara, CA, USA). The catalysts (500 mg) was dissolved in $10 \mathrm{~mL}$ of $\mathrm{H}_{2} \mathrm{SO}_{4}(1: 1)$ and the solution was heated. After complete dissolution, the solution was cooled down and diluted with demineralized water. Then, the solution was heated to $100{ }^{\circ} \mathrm{C}$ for a few minutes. After cooling to laboratory temperature, the solution was transported to volumetric flask and the determination of metals was performed. 
The mineralization of the products of aldol condensation was performed before the ICP-OES analyzes. The product was stirred with p-toluenesulfonic acid $(10: 1 \mathrm{~g} / \mathrm{g})$ for $10 \mathrm{~min}$ and then the mixture was transformed to ash by slow heating up to $50{ }^{\circ} \mathrm{C}$ in a muffle oven. The ash was then dissolved in sulphuric acid and the solution was analyses by ICP-OES. The calibration curve method was used for quantification of the metals in the products of aldol condensation. Powder X-ray diffraction (XRD) of LDHs and mixed oxides was performed with diffractometer Bruker D8 Advance ECO (Bruker AXS GmbH, Karlsruhe, Germany) equipped with the $\mathrm{Cu} K \alpha$ radiation $(\lambda=0.154056 \mathrm{~nm})$ and with a secondary graphite monochromator. The measurement was carried out in $2 \theta$ range from $5^{\circ}$ to $70^{\circ}$. Diffrac.Eva software with the Powder Diffraction File database (PDF 4+, 2018, International Centre for Diffraction Data) was used for the evaluation of XRD pattern. The main reflections at $2 \theta=11.3^{\circ}$ for $\mathrm{LDH}$ and at $2 \theta=43.2^{\circ}$ for mixed oxides were used for determination of the crystal sizes, using the Scherrer equation [15].

$$
\mathrm{D}_{\text {cryst }}=(0.9 \cdot \lambda) /(\beta \cdot \cos \theta),
$$

Thermogravimetric analysis (TGA) of LDH was performed using TA Instruments TGA Discovery series equipped with a mass spectrometer (quadrupole analyzer) OmniStar GSD 320 from Pfeiffer Vacuum. LDH (20 mg), placed in an open alumina crucible, was heated from room temperature to $900{ }^{\circ} \mathrm{C}\left(10^{\circ} \mathrm{C} / \mathrm{min}\right)$ under nitrogen flow $\left(20 \mathrm{~mL} \cdot \mathrm{min}^{-1}\right.$, Linde 5.0$)$.

Specific surface area (SBET) was determined by nitrogen physisorption (77 K) performed by Autosorb iQ instrument (Quantachrome Instruments, Gratz, Austria). Prior to the measurement, each $\mathrm{LDH}$ was degassed in a glass-cell at $110{ }^{\circ} \mathrm{C}$ under vacuum for $16 \mathrm{~h}$ The BET isotherm was used for the determination of specific surface area denoted as $\mathrm{S}_{\mathrm{BET}}\left(\mathrm{m}^{2} / \mathrm{g}\right)$.

The temperature-programmed desorption of probe molecules $\mathrm{CO}_{2}\left(\mathrm{CO}_{2}\right.$-TPD) was performed by Micromeritics AutoChem II 2920 (Micromeritics Instrument Corp., Norcross, GA, USA) equipped with a mass spectrometer Pfeiffer Vacuum OmniStar ${ }^{\mathrm{TM}}$ GSD 320 (Pfeiffer Vacuum, Prague, Czech Republic). Approximately, $100 \mathrm{mg}$ of the rehydrated mixed oxide was inserted in a quartz reactor. The degassing was carried out at $100{ }^{\circ} \mathrm{C}\left(10^{\circ} \mathrm{C} \cdot \mathrm{min}^{-1}\right)$ for $5 \mathrm{~min}$ in a flow of helium $\left(25 \mathrm{~mL} \cdot \mathrm{min}^{-1}\right)$. Then the temperature was decreased to $25^{\circ} \mathrm{C}$ and the rehydrated mixed oxide was saturated in a flow of gas mixture (10 vol\% of $\mathrm{CO}_{2}$ in helium) for $30 \mathrm{~min}$. The physically adsorbed molecules of $\mathrm{CO}_{2}$ were removed by purging of helium flow for $60 \mathrm{~min}$. Finely, the desorption was carried out under linear heating of the rehydrated mixed oxides $\left(10^{\circ} \mathrm{C} \cdot \mathrm{min}^{-1}\right)$ in a flow of $\mathrm{He}\left(25 \mathrm{~mL} \cdot \mathrm{min}^{-1}\right)$.

\subsection{Catalytic Test}

The reaction was carried out in a glass reactor formed by three-necked $100 \mathrm{~mL}$ flask placed in a water bath and equipped with a reflux condenser and a thermometer. A reactant mixture placed in the reactor consisted typically of $6.5 \mathrm{~g}$ furfural and desired amount of acetone (Furfural: Acetone ratio 1: 10; mol: mol). Before the use, acetone was dried using molecular sieves $3 \mathrm{~A}$ to avoid affecting the catalyst activity by dissolved water. After reactants insertion, the reaction mixture was heated under mild stirring until the temperature of $50^{\circ} \mathrm{C}$ was reached, then the catalyst was added the stirring rate was increased to $550 \mathrm{rpm}$. The samples of the reaction mixture were withdrawn at defined reaction times i.e., 0, 5, 10, 20, 40, 80, 120, 180 and $240 \mathrm{~min}$ for each experiment. Before GC analysis of the samples, the catalysts were separated from them by filtration. The liquid product was analyzed by GC-FID (Agilent Technologies Inc., Santa Clara, CA, USA) equipped by capillary column (HP 5 column: $30 \mathrm{~m} / 0.32 \mathrm{~mm} \mathrm{ID} / 0.25 \mu \mathrm{m}$ ) and the concentration of the feedstock and main products was evaluated by calibration curve method. The conversion of furfural (Xfurf) and selectivity to FAc-OH ( $\left.\mathrm{S}_{\mathrm{FAc}-\mathrm{OH}}\right)$, FAc $\left(\mathrm{S}_{\mathrm{FAc}}\right)$ and F2Ac $\left(\mathrm{S}_{\mathrm{F} 2 \mathrm{Ac}}\right)$ were calculated by Equations (2)-(5).

$$
\mathrm{X}_{\text {fur }}=\left(\frac{\mathrm{n}_{\text {fur }}^{\text {before }}-\mathrm{n}_{\text {fur }}^{\text {after }}}{\mathrm{n}_{\text {fur }}^{\text {before }}}\right) \cdot 100
$$




$$
\begin{gathered}
\mathrm{S}_{\mathrm{FAc}-\mathrm{OH}}=\left(\frac{\mathrm{n}_{\mathrm{FAc}-\mathrm{OH}}}{\mathrm{n}_{\text {fur }}^{\text {before }}-\mathrm{n}_{\text {fur }}^{\text {after }}}\right) \cdot 100 \\
\mathrm{~S}_{\mathrm{FAc}}=\left(\frac{\mathrm{n}_{\mathrm{FAc}}}{n_{\text {fur }}^{\text {before }}-\mathrm{n}_{\text {fur }}^{\text {after }}}\right) \cdot 100 \\
\mathrm{~S}_{\mathrm{F} 2 \mathrm{Ac}}=\left(\frac{2 \mathrm{n}_{\mathrm{FAc}-\mathrm{OH}}}{\mathrm{n}_{\text {fur }}^{\text {before }}-\mathrm{n}_{\mathrm{fur}}^{\text {after }}}\right) \cdot 100
\end{gathered}
$$

where $\mathrm{n}_{\text {fur }}^{\text {before }}, \mathrm{n}_{\text {fur }}^{\text {after }}$ are the amount of furfural in feedstock and products, respectively. The amount of the FAc-OH, FAc and F2Ac are denoted as $\mathrm{n}_{\mathrm{FAc}-\mathrm{OH}}, \mathrm{n}_{\mathrm{FAc}}, \mathrm{n}_{\mathrm{FAc}-\mathrm{OH}}$, respectively.

\section{Conclusions}

The $\mathrm{Mg}$-Fe LDHs with the $\mathrm{Mg} / \mathrm{Fe}$ molar ratio varying from 1 to 10 were prepared by the co-precipitation method. In second step, they were calcined at $500{ }^{\circ} \mathrm{C}$ to yield mixed oxides which were then rehydrated to recover the layered LDH structure again. Their properties and their catalytic efficiency in the aldol condensation of furfural with acetone were then studied.

It was confirmed that the double-layered structure was perfectly recovered by rehydration of the mixed oxides with the $\mathrm{Mg} / \mathrm{Fe}$ molar ratio of 3:1 and 4:1. The rehydrated mixed oxides with the $\mathrm{Mg} / \mathrm{Fe}$ molar ratio below or above said interval contained admixtures of other phases, such as $\mathrm{MgO}$, brucite, magnetite. These impurities affect basicity of the catalysts. Total catalysts basicity increased in line with the $\mathrm{Mg} / \mathrm{Fe}$ molar ratio up to 4:1, the maximum total basicity achieving the value of $1506 \mu \mathrm{mol} / \mathrm{g}$. Then the total basicity started decreasing with further increase of magnesium content. The furfural conversion correlated well with the density of basic sites. Apparently, not only a whole amount of basic sites but also their density is important for the catalyst activity in aldol condensation.

Very active $\mathrm{Mg}-\mathrm{Fe}$ catalysts, over which full furfural conversion, within a short period of reaction time, could be achieved, were prepared by the rehydration of the mixed oxides obtained by the thermal decomposition of the $\mathrm{Mg}$-Fe LDH structures. The most active catalysts were obtained from those mixed oxides in which the $\mathrm{Mg} / \mathrm{Fe}$ molar ratio ranged from 3:1 to 4:1. In these oxides pure LDH structure without undesirable admixtures was recovered by rehydration.

Besides high activity, the rehydrated $\mathrm{Mg}$-Fe mixed oxides were also very stable in the aldol condensation of furfural with acetone, the leaching of their metals into the reaction mixture being negligible. So they can be considered as having a good potential for the preparation of oxygen containing components for modern fuels.

Author Contributions: Conceptualization, K.J. (Kocík Jaroslav), methodology, T.Z., validation, A.U., formal analysis, T.Z., K.J. (Kocík Jaroslav), investigation, K.J. (Kocík Jaroslav), resources, A.U., data curation, K.J. (Kolena Jiří), writing—original draft preparation, K.J. (Kocík Jaroslav), A.U., writing-review and editing, K.J. (Kolena Jiří), project administration, K.J. (Kocík Jaroslav), funding acquisition, K.J. (Kocík Jaroslav), All authors have read and agreed to the published version of the manuscript.

Funding: This research was funded by Czech Science Foundation, grant number 19-00669S.

Acknowledgments: This publication is the result of the project reg. no. 19-00669S which has been financially supported by the Czech Science Foundation. The project has been integrated into the National Sustainability Programme I of the Ministry of Education, Youth and Sports of the Czech Republic (MEYS) through the project Development of the UniCRE Centre (LO1606). The result was achieved using the infrastructure included in the project Efficient Use of Energy Resources Using Catalytic Processes (LM2018119) which has been financially supported by MEYS within the targeted support of large infrastructures. In this section you can acknowledge any support given which is not covered by the author contribution or funding sections. This may include administrative and technical support, or donations in kind (e.g., materials used for experiments).

Conflicts of Interest: The authors declare no conflict of interest. The funders had no role in the design of the study; in the collection, analyses, or interpretation of data; in the writing of the manuscript, or in the decision to publish the results. 


\section{References}

1. Ghorbel, S.B.; Medina, F.; Ghorbel, A.; Segarra, A.M. Phosphoric acid intercalated Mg-Al hydrotalcite-like compounds for catalytic carboxylation reaction of methanol in a continuous system. Appl. Catal. A Gen. 2015, 493, 142-148. [CrossRef]

2. Nawfal, M.; Gennequin, C.; Labaki, M.; Nsouli, B.; Aboukaïs, A.; Abi-Aad, E. Hydrogen production by methane steam reforming over $\mathrm{Ru}$ supported on $\mathrm{Ni}-\mathrm{Mg}-\mathrm{Al}$ mixed oxides prepared via hydrotalcite route. Int. J. Hydrog. Energy 2015, 40, 1269-1277. [CrossRef]

3. Chakraborty, S.; Sarkar, I.; Haldar, K.; Pal, S.K.; Chakraborty, S. Synthesis of Cu-Al layered double hydroxide nanofluid and characterization of its thermal properties. Appl. Clay Sci. 2015, 107, 98-108. [CrossRef]

4. Xie, W.; Peng, H.; Chen, L. Calcined Mg-Al hydrotalcites as solid base catalysts for methanolysis of soybean oil. J. Mol. Catal. A Chem. 2006, 246, 24-32. [CrossRef]

5. Hajek, M.; Kutalek, P.; Smolakova, L.; Troppova, I.; Capek, L.; Kubicka, D.; Kocik, J.; Thanh, D.N. Transesterification of rapeseed oil by $\mathrm{Mg}-\mathrm{Al}$ mixed oxides with various $\mathrm{Mg} / \mathrm{Al}$ molar ratio. Chem. Eng. J. 2015, 263, 160-167. [CrossRef]

6. Kocík, J.; Frolich, K.; Perková, I.; Horáček, J. Pyroaurite-based Mg Fe mixed oxides and their activity in aldol condensation of furfural with acetone: Effect of oxide composition. J. Chem. Technol. Biotechnol. 2019, 94, 435-445. [CrossRef]

7. Prescott, H.A.; Li, Z.J.; Kemnitz, E.; Trunschke, A.; Deutsch, J.; Lieske, H.; Auroux, A. Application of calcined Mg-Al hydrotalcites for Michael additions: An investigation of catalytic activity-and acid-base properties. J. Catal. 2005, 234, 119-130. [CrossRef]

8. Dumbre, D.K.; Mozammel, T.; Selvakannan, P.R.; Hamid, S.B.A.; Choudhary, V.R.; Bhargava, S.K. Thermally decomposed mesoporous Nickel Iron hydrotalcite: An active solid-base catalyst for solvent-free Knoevenagel condensation. J. Colloid Interface Sci. 2015, 441, 52-58. [CrossRef]

9. Climent, M.J.; Corma, A.; Iborra, S.; Primo, J. Base Catalysis for Fine Chemicals Production-Claisen-Schmidt Condensation on Zeolites and Hydrotalcites for the Production of Chalcones and Flavanones of Pharmaceutical Interest. J. Catal. 1995, 151, 60-66. [CrossRef]

10. Kikhtyanin, O.; Tisler, Z.; Velvarska, R.; Kubicka, D. Reconstructed Mg-Al hydrotalcites prepared by using different rehydration and drying time: Physico-chemical properties and catalytic performance in aldol condensation. Appl. Catal. A-Gen. 2017, 536, 85-96. [CrossRef]

11. Alonso, D.M.; Bond, J.Q.; Dumesic, J.A. Catalytic conversion of biomass to biofuels. Green Chem. 2010, 12, 1493-1513. [CrossRef]

12. Thanh, D.N.; Kikhtyanin, O.; Ramos, R.; Kothari, M.; Ulbrich, P.; Munshi, T.; Kubicka, D. Nanosized TiO ${ }_{2}-\mathrm{A}$ promising catalyst for the aldol condensation of furfural with acetone in biomass upgrading. Catal. Today 2016, 277, 97-107. [CrossRef]

13. Hua, D.R.; Wu, Y.L.; Liu, Y.F.; Chen, Y.; Yang, M.D.; Lu, X.N.; Li, J. Preparation of furfural and reaction kinetics of xylose dehydration to furfural in high-temperature water. Pet. Sci. 2016, 13, 167-172. [CrossRef]

14. Marchal, R.; Ropars, M.; Pourquié, J.; Fayolle, F.; Vandecasteele, J.P. Large-scale enzymatic hydrolysis of agricultural lignocellulosic biomass. Part 2: Conversion into acetone-butanol. Bioresour. Technol. 1992, 42, 205-217. [CrossRef]

15. Shekoohi, K.; Hosseini, F.S.; Haghighi, A.H.; Sahrayian, A. Synthesis of some Mg/Co-Al type nano hydrotalcites and characterization. MethodsX 2017, 4, 86-94. [CrossRef]

16. Lavalley, J.C. Infrared spectrometric studies of the surface basicity of metal oxides and zeolites using adsorbed probe molecules. Catal. Today 1996, 27, 377-401. [CrossRef]

17. Constantino, V.R.L.; Pinnavaia, T.J. Basic Properties of Mg1-X(2+)Alx(3+) Layered Double Hydroxides Intercalated by Carbonate, Hydroxide Chloride and Sulfate Anions. Inorg. Chem. 1995, 34, 883-892. [CrossRef]

18. Yun, S.K.; Pinnavaia, T.J. Water-Content and Particle Texture of Synthetic Hydrotalcite-Like Layered Double Hydroxides. Chem. Mater. 1995, 7, 348-354. [CrossRef]

19. Cavani, F.; Trifiro, F.; Vaccari, A. Hydrotalcite-Type Anionic Clays: Preparation, Properties and Applications. Catal. Today 1991, 11, 173-301. [CrossRef] 
20. Kikhtyanin, O.; Čapek, L.; Smoláková, L.; Tišler, Z.; Kadlec, D.; Lhotka, M.; Diblíková, P.; Kubička, D. Influence of Mg-Al Mixed Oxide Compositions on Their Properties and Performance in Aldol Condensation. Ind. Eng. Chem. Res. 2017, 56, 13411-13422. [CrossRef]

21. Chen, Y.; Zhou, T.; Fang, H.; Li, S.; Yao, Y.; Fan, B.; Wang, J. A novel preparation of nanosized hexagonal $\mathrm{Mg}(\mathrm{OH})_{2}$ as a flame retardant. Particuology 2016, 24, 177-182. [CrossRef]

22. Gong, W.; Wu, D.; Cheng, Z.; Pang, H.; Lin, Y.; Ning, G. Direct synthesis of porous $\mathrm{Mg}(\mathrm{OH})_{2}$ nanoplates from natural brucite. Mater. Res. Bull. 2013, 48, 1333-1337. [CrossRef]

23. Kikhtyanin, O.; Capek, L.; Tisler, Z.; Velvarska, R.; Panasewicz, A.; Diblikova, P.; Kubicka, D. Physico-Chemical Properties of MgGa Mixed Oxides and Reconstructed Layered Double Hydroxides and Their Performance in Aldol Condensation of Furfural and Acetone. Front. Chem. 2018, 6, 176. [CrossRef] [PubMed]

24. Hora, L.; Kelbichová, V.; Kikhtyanin, O.; Bortnovskiy, O.; Kubička, D. Aldol condensation of furfural and acetone over MgAl layered double hydroxides and mixed oxides. Catal. Today 2014, 223, 138-147. [CrossRef]

Publisher's Note: MDPI stays neutral with regard to jurisdictional claims in published maps and institutional affiliations.

(C) 2020 by the authors. Licensee MDPI, Basel, Switzerland. This article is an open access article distributed under the terms and conditions of the Creative Commons Attribution (CC BY) license (http://creativecommons.org/licenses/by/4.0/). 